\title{
Article \\ Alternative Pathway Is Involved in Hydrogen Peroxide-Enhanced Cadmium Tolerance in Hulless Barley Roots
}

\author{
Li He 1,2,3, Xiaomin Wang 1,2,4 Xiaofan $\mathrm{Na}^{1,2,4}$, Ruijun Feng ${ }^{2}$, Qiang $\mathrm{He}^{2}$, Shengwang Wang ${ }^{2}$, Cuifang Liang ${ }^{2}$, \\ Lili Yan ${ }^{2}$, Libin Zhou ${ }^{4, *}$ and Yurong Bi ${ }^{1,2,4, *(D)}$ \\ 1 State Key Laboratory of Hulless Barley and Yak Germplasm Resources and Genetic Improvement, \\ Lhasa 850002, China; hel16@lzu.edu.cn (L.H.); wangxiaomin@lzu.edu.cn (X.W.); naxf@lzu.edu.cn (X.N.) \\ 2 Ministry of Education Key Laboratory of Cell Activities and Stress Adaptations, School of Life Sciences, \\ Lanzhou University, Lanzhou 730000, China; fengrj16@lzu.edu.cn (R.F.); hjtywjb@163.com (Q.H.); \\ wangshw16@lzu.edu.cn (S.W.); liangcf16@lzu.edu.cn (C.L.); yanll18@lzu.edu.cn (L.Y.) \\ 3 School of Biological and Pharmaceutical Engineering, Lanzhou Jiaotong University, Lanzhou 730070, China \\ 4 Biophysics Group, Institute of Modern Physics, Chinese Academy of Sciences, Lanzhou 730000, China \\ * Correspondence: libinzhou@impcas.ac.cn (L.Z.); yrbi@lzu.edu.cn (Y.B.)
}

Citation: He, L.; Wang, X.; Na, X.; Feng, R.; He, Q.; Wang, S.; Liang, C.; Yan, L.; Zhou, L.; Bi, Y. Alternative Pathway Is Involved in Hydrogen Peroxide-Enhanced Cadmium Tolerance in Hulless Barley Roots. Plants 2021, 10, 2329. https:// doi.org/10.3390/plants10112329

Academic Editor: Rene Kizek

Received: 20 September 2021

Accepted: 23 October 2021

Published: 28 October 2021

Publisher's Note: MDPI stays neutral with regard to jurisdictional claims in published maps and institutional affiliations.

Copyright: (c) 2021 by the authors. Licensee MDPI, Basel, Switzerland. This article is an open access article distributed under the terms and conditions of the Creative Commons Attribution (CC BY) license (https:// creativecommons.org/licenses/by/ $4.0 /)$.

\begin{abstract}
Hulless barley, grown in the Qinghai Tibet Plateau, has a wide range of environmental stress tolerance. Alternative pathway (AP) and hydrogen peroxide $\left(\mathrm{H}_{2} \mathrm{O}_{2}\right)$ are involved in enhancing plant tolerance to environmental stresses. However, the relationship between $\mathrm{H}_{2} \mathrm{O}_{2}$ and AP in hulless barley tolerance to cadmium $(\mathrm{Cd})$ stress remains unclear. In the study, the role and relationship of $\mathrm{AP}$ and $\mathrm{H}_{2} \mathrm{O}_{2}$ under $\mathrm{Cd}$ stress were investigated in hulless barley (Kunlun14) and common barley (Ganpi6). Results showed that the expression level of alternative oxidase (AOX) genes (mainly AOX1a), AP capacity $\left(\mathrm{V}_{\text {alt }}\right)$, and AOX protein were clearly induced more in Kunlun14 than in Ganpi 6 under Cd stress; moreover, these parameters were further enhanced by applying $\mathrm{H}_{2} \mathrm{O}_{2}$. Malondialdehyde (MDA) content, electrolyte leakage (EL) and NAD(P)H to NAD(P) ratio also increased in Cd-treated roots, especially in Kunlun 14, which can be markedly alleviated by exogenous $\mathrm{H}_{2} \mathrm{O}_{2}$. However, this mitigating effect was aggravated by salicylhydroxamic acid (SHAM, an AOX inhibitor), suggesting AP contributes to the $\mathrm{H}_{2} \mathrm{O}_{2}$-enhanced $\mathrm{Cd}$ tolerance. Further study demonstrated that the effect of SHAM on the antioxidant enzymes and antioxidants was minimal. Taken together, hulless barley has higher tolerance to $\mathrm{Cd}$ than common barley; and in the process, AP exerts an indispensable function in the $\mathrm{H}_{2} \mathrm{O}_{2}$-enhanced $\mathrm{Cd}$ tolerance. AP is mainly responsible for the decrease of ROS levels by dissipating excess reducing equivalents.
\end{abstract}

Keywords: alternative pathway; Cd stress; hulless barley; hydrogen peroxide; reactive oxygen species

\section{Introduction}

Cadmium $(\mathrm{Cd})$, the third major contaminant to the environments, is seriously harmful to organisms, even human health [1,2]. Cd can affect plant growth and development, such as yellowing of leaves, necrosis of roots, inhibition of photosynthesis, changes of transpiration and respiration rate $[3,4]$. Moreover, $\mathrm{Cd}$ can damage DNA and change protein structure [5]. In cells, the over-accumulated Cd can disrupt the redox homoeostasis and further result in oxidative stresses [6]. In order to reduce the toxicity of $C d$, plants have developed a variety of defense mechanism [7].

Plants can suppress $\mathrm{Cd}$ uptake to maintain a low $\mathrm{Cd}$ concentration, thus avoiding heavy metal toxicity [8]. Meanwhile, chelating and sequestrating $\mathrm{Cd}$ to insensitive compartments of cells (e.g., vacuoles) was verified to be momentous in Cd detoxification [9]. The activation of antioxidant defense system has been widely proven to be an essential way to resist Cd-induced oxidative stress [10]. A series of heavy metal transport-associated proteins, such as yellow stripe-like protein (YSL), natural resistance-associated macrophage protein (NRAMP), and heavy metal transporting ATPase (HMA), transport heavy metal 
ions to outside of the cytoplasm, thus maintaining the intracellular ion homeostasis and enhancing $\mathrm{Cd}$ tolerance [11]. In addition, alternative pathway (AP) has been extensively reported to enhance $\mathrm{Cd}$ tolerance [8]. Even so much previous effort has been made, the in-depth protective mechanisms in plant tolerance to $\mathrm{Cd}$ stress is still unclear.

$\mathrm{H}_{2} \mathrm{O}_{2}$ signal is widely involved in the plant responses to biotic and abiotic stresses [12]. Only high-concentration $\mathrm{H}_{2} \mathrm{O}_{2}$ can lead to serious oxidative damages. Under aluminum (Al) stress, $\mathrm{H}_{2} \mathrm{O}_{2}$ can obviously recover the Al-induced root growth inhibition and reduce $\mathrm{Al}$ accumulation in roots through improving antioxidant enzyme activities and gene expression in peanut roots [10]. $\mathrm{H}_{2} \mathrm{O}_{2}$ regained crop development and subsequent activation of MPK $1 / 2$ by enhancing the activities of antioxidant enzymes and the content of AsA and GSH under Cd tolerance in Solanum lycopersicum [13]. Moreover, $\mathrm{H}_{2} \mathrm{O}_{2}$ was found to improve thiol content, antioxidant enzyme activities, activation of metallothionein protein (BnMP1) mRNA and decrease lipid peroxidation in Brassica napus exposed to chromium (Cr) stress [14]. $\mathrm{H}_{2} \mathrm{O}_{2}$ was also reported to be involved in signal perception and transduction of cold stress in Synechocystis [15]. Meanwhile, $\mathrm{H}_{2} \mathrm{O}_{2}$ protects bacteria from oxidative stress via modulating the activity of transcription factors OxyR and PerR [16]. In addition, $\mathrm{H}_{2} \mathrm{O}_{2}$ regulates the ethylene signal in response to the hypoxic stress [17]. These results confirm that a suitable $\mathrm{H}_{2} \mathrm{O}_{2}$ concentration can strengthen the tolerance of plants to environmental stresses. However, it is still unclear about the role of $\mathrm{H}_{2} \mathrm{O}_{2}$ in hulless barley tolerance to Cd stress.

Respiration metabolism plays fundamental functions in plant growth and development. Plant mitochondria have an alternative pathway (AP) in addition to the cyanidesensitive cytochrome pathway (CP) [18]. Alternative oxidase (AOX) is the terminal oxidase of $\mathrm{AP}$, and is located in the mitochondria inner membrane [18]. When plants are exposed to environmental stresses, the AP capacity can be significantly increased [19]. In hulless barley, AP capacity and AOX protein level were markedly increased under low-nitrogen stress [20], and exposure to UV-B radiation [21]. It was reported that Cd stress significantly inhibited the CP capacity, but induced the AP capacity in Euglena [22]. In Arabidopsis, AP capacity and AOX protein level were also increased under Cd stress [23]. It was reported that $\mathrm{H}_{2} \mathrm{O}_{2}$ is involved in regulating the transcription of $A O X$ family genes in M. grisea [24]. In addition, $\mathrm{H}_{2} \mathrm{O}_{2}$ induced $\mathrm{AP}$ in chill and salt stress $[25,26]$. However, the relationship and the mechanism between AP and $\mathrm{H}_{2} \mathrm{O}_{2}$ in the highland barley tolerance to $\mathrm{Cd}$ stress are still unknown.

Hulless barley is an ideal material to explore the mechanism of crop tolerance because it grows in such harsh climate conditions [21]. In this study, we explored the role of $\mathrm{H}_{2} \mathrm{O}_{2}$ and AP in hulless barley response to Cd stress. The results showed that AP is involved in $\mathrm{H}_{2} \mathrm{O}_{2}$-enhanced $\mathrm{Cd}$ tolerance in hulless barley by dissipating excess reducing equivalents.

\section{Materials and Methods}

\subsection{Plant Materials and Growth Conditions}

Hulless barley (Kunlun14) and common barley (Ganpi6) were provided by Prof. Kunlun Wu (Qinghai Academy of Agriculture and Forestry Sciences, Xi'ning, China). The seeds were treated with $2 \% \mathrm{NaClO}$ for $10 \mathrm{~min}$, and washed with sterile water for at least 3 times. Then the seeds were germinated and grown in $200 \mathrm{~mL}$ plastic beakers filled with 1/4-strengh Hoagland culture solution [27]. Culture solution was changed every other day.

After $6 \mathrm{~d}$ growth, seedlings were used for treatments. $150 \mu \mathrm{M} \mathrm{CdCl}_{2}$ was added in the $1 / 4$ Hoagland solution for $48 \mathrm{~h}$ as the Cd stress. $150 \mu \mathrm{M}$ salicylhydroxamic acid (SHAM) was used to inhibit the alternative oxidase (AOX) activity. A total of $20 \mu \mathrm{M}$ hydrogen peroxide $\left(\mathrm{H}_{2} \mathrm{O}_{2}\right)$ was added in solution for $48 \mathrm{~h}$. Roots were collected for the following experiments.

\section{2. $\mathrm{H}_{2} \mathrm{O}_{2}$ Staining}

$\mathrm{H}_{2} \mathrm{O}_{2}$ staining was performed following the method described by Skórzyńska et al. [28]. Roots were stained in $2 \mathrm{mg} / \mathrm{mL}$ 3,3-diaminobenzidine (DAB) solution for $10 \mathrm{~h}$, and 
photographed using the Leica SM IRBE stereomicroscope (Leica Microsystems, Wetzlar, Germany).

\subsection{Determination of Electrolyte Leakage and Malondialdehyde Content}

Electrolyte leakage (EL) and malondialdehyde (MDA) content in roots were determined according to the method described by Janicka et al. [29].

\subsection{Measurements of Respiratory Rates}

Respiratory rate was detected as described by Wang et al. [30]. $0.05 \mathrm{~g}$ of roots were cut into small segments, and then put into the reaction vessel containing $2 \mathrm{~mL}$ phosphate buffer ( $\mathrm{pH}$ 6.8). After reaction for $2 \mathrm{~min}$, oxygen consumption rate was measured, and this rate was defined as the total respiratory rate $\left(\mathrm{V}_{\mathrm{t}}\right)$. After $2 \mathrm{mM} \mathrm{KCN}$ or $2 \mathrm{mM}$ salicylhydroxamic acid (SHAM) was added into the reaction vessel for $2 \mathrm{~min}$; the oxygen consumption rate was defined as the alternative pathway capacity $\left(\mathrm{V}_{\text {alt }}\right)$ or the cytochrome pathway capacity $\left(\mathrm{V}_{\text {cyt }}\right)$, respectively.

\subsection{Determination of Antioxidant Contents}

Total ascorbic acid (AsA) content, reduced AsA and oxidized AsA were measured according to the method described by Paradiso et al. [27]. Oxidized glutathione (GSSG) and reduced glutathione (GSH) contents were measured according to the method described by Paradiso et al. [27].

\subsection{Antioxidant Enzyme Activity Assay}

The enzymes were extracted according to the method of Pinto et al. [28]. Antioxidant enzyme activities (SOD, CAT, POD and APX) were analyzed following the method described by Jian et al. [29]. The activities of the GSH-AsA cycle-related enzymes (DHAR, MDHAR, GR and GPX) were determined according to the method described by Zhang et al. [4].

\subsection{RNA Isolation and $q R T-P C R$}

RNA isolation and qRT-PCR were carried out according to the method of He et al. [30]. The gene-specific primers were listed in Table 1. HvACTIN was used as the reference gene. qRT-PCR data were quantified using the $2^{-\triangle \triangle \mathrm{CT}}$ method.

Table 1. Primer Sequences.

\begin{tabular}{cc}
\hline Primer Name & Primer Sequence $\mathbf{( 5}^{\prime}$ to $\mathbf{3}^{\prime} \mathbf{)}$ \\
\hline qHvAOX1a-F & GCAACGAACCTACAAGCGTG \\
qHvAOX1a-R & AAGAGCCCAGCACCAACAA \\
qHvAOX1d1-F & CCTCCCATTAGCTTTTCGACCAG \\
qHvAOX1d1-R & CGVAOX1d2-F \\
qHvAOX1d2-R & TACGACCACGAGTTTCGCGAGCA \\
HvMnSOD-F & GCTAAAGAGCCCTCATTTCCTC \\
HvMnSOD-R & CAGGTCGTACAACWCGATTA \\
HvFeSOD-F & CGTCAAGAAATCCAAACAGTC \\
HvFeSOD-R & GCAACGTTGGTACAACGGA \\
HvPOD-F & CGTAAAGAGCGTCATTTGG \\
HvPOD-R & GGTCCCATTACCTTTTCGTGGTC \\
HvCAT1-F & GCCTAGCACGTAACACGCTGACT \\
HvCAT1-R & TAGCAGGACGAGTAACGCCTGGT \\
HvCAT2-F & CGTAAAGAGCCCTCTAATCG \\
HvCAT2-R & GCAACGAACCTACAACCGTC \\
HvAPX-F & AAGAGCCCAGCACCAACAAT \\
HvAPX-R & GCTCCCATTAGCTTTTCGACAC \\
HvACTIN-F & GCCTAGCACGTAACAGCGTTCA \\
HvACTIN-R & GTGGTCGTACAACWGGTATTGTG \\
\hline
\end{tabular}




\subsection{Western-Blot Analysis}

Western-blot analysis was conducted following the method described by Zhao et al. [21]. Proteins were separated on $12.5 \%$ acrylamide gel, then transferred to polyvinylidene difluoride membrane. The membrane was blocked for $3 \mathrm{~h}$ with $10 \%$ bovine serum albumin. Primary antibody against Arabidopsis AOX was added and incubated overnight. After rinsing three times with TTBS [ $15 \mathrm{mM} \mathrm{NaCl}, 0.05 \%$ Tween-20, $1 \mathrm{mM}$ Tris- $\mathrm{HCl}$ (pH 8.0)], secondary antibody was added and incubated for visualization according to the instructions of the luminescence kit (NCM BIotech; Suzhou; China).

\subsection{Statistical Analysis}

Each experiment was repeated at least three times. The date was analyzed by SPSS 17.0 and Origin 8. Different lowercase letters indicate significant difference at $p<0.05$.

\section{Results}

\subsection{Effects of $\mathrm{Cd}$ Stress on $\mathrm{H}_{2} \mathrm{O}_{2}$ Content}

To explore whether $\mathrm{H}_{2} \mathrm{O}_{2}$ is involved in enhancing hulless barley tolerance to $\mathrm{Cd}$ stress, the $\mathrm{H}_{2} \mathrm{O}_{2}$ content was analyzed under Cd Stress by 3,3-diaminobenzidine (DAB) histochemical staining. The optimum Cd concentration $(150 \mu \mathrm{M})$ for barley was selected in our previous research [30]. As shown in Figure 1, with the increase of Cd concentration, the $\mathrm{H}_{2} \mathrm{O}_{2}$ staining was gradually deepened in Ganpi6 and Kunlun14 roots. Under $150 \mu \mathrm{M}$ $\mathrm{Cd}, \mathrm{H}_{2} \mathrm{O}_{2}$ staining was increased by $5.26 \times$ and $4.18 \times$ in Ganpi6 and Kunlun14 roots, respectively. When $\mathrm{Cd}$ concentration was increased to $200 \mu \mathrm{M}$, the $\mathrm{H}_{2} \mathrm{O}_{2}$ staining was no longer increased. These results indicated that $\mathrm{Cd}$ stress can significantly induce $\mathrm{H}_{2} \mathrm{O}_{2}$ accumulation, which was significantly lower in Kunlun14 than that in Ganpi6, suggesting that Ganpi6 suffered more oxidative stress in comparison with Kunlun 14 under Cd stress.
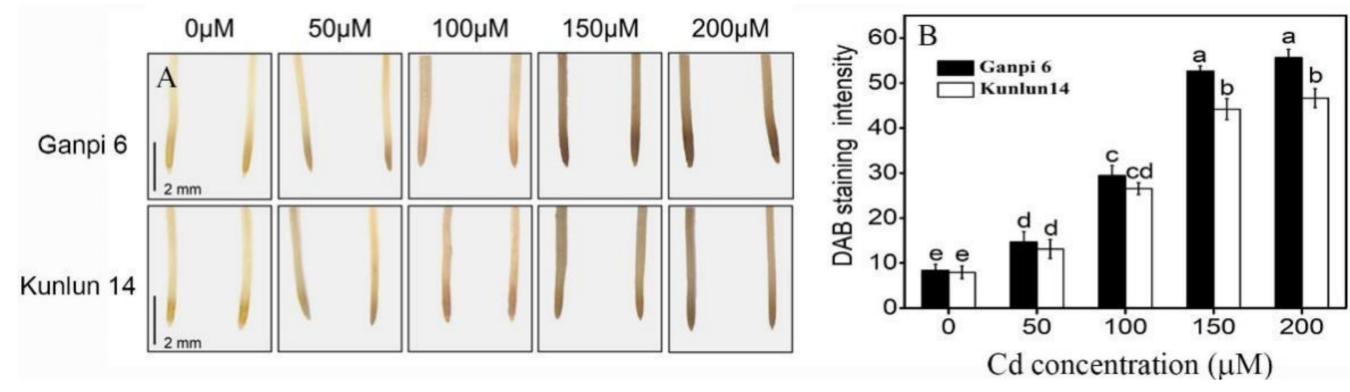

Figure 1. Effects of $\mathrm{Cd}$ on $\mathrm{H}_{2} \mathrm{O}_{2}$ content in Ganpi6 and Kunlun14 roots. (A) Histochemical staining of $\mathrm{H}_{2} \mathrm{O}_{2} ;$ (B) quantification of $\mathrm{H}_{2} \mathrm{O}_{2}$ content. Six-day-old seedlings were grown in 1/4-strengh Hoagland nutrient solution with 0-200 $\mu \mathrm{M} \mathrm{Cd}$ for $48 \mathrm{~h} . \mathrm{H}_{2} \mathrm{O}_{2}$ level was examined by histochemical method. Different lower case letters represent significant difference at $p<0.05$.

To analyze whether $\mathrm{H}_{2} \mathrm{O}_{2}$ has protective effects on Ganpi6 and Kunlun14 roots under Cd stress, exogenous $\mathrm{H}_{2} \mathrm{O}_{2}(10,20$ and $30 \mu \mathrm{M})$ were applied under $150 \mu \mathrm{M}$ Cd treatment. $\mathrm{H}_{2} \mathrm{O}_{2}$ function was evaluated by measuring the MDA content and EL level. As shown in Figure 2, after $150 \mu \mathrm{M} \mathrm{Cd}+\mathrm{H}_{2} \mathrm{O}_{2}$ treatment for $48 \mathrm{~h}, 20 \mu \mathrm{M} \mathrm{H}_{2} \mathrm{O}_{2}$ significantly reduced the MDA content and EL level in Ganpi6 and Kunlun14 roots. However, when $\mathrm{H}_{2} \mathrm{O}_{2}$ concentration was increased to $30 \mu \mathrm{M}$, the MDA content and EL level gradually increased to the level of $10 \mu \mathrm{M} \mathrm{H}_{2} \mathrm{O}_{2}$ treatment. These results suggested that $20 \mu \mathrm{M}$ of $\mathrm{H}_{2} \mathrm{O}_{2}$ has the best effect on alleviating the $\mathrm{Cd}$-induced oxidative stress. So $20 \mu \mathrm{M} \mathrm{H}_{2} \mathrm{O}_{2}$ was used in the further study. In addition, upon $\mathrm{Cd}+20 \mu \mathrm{M} \mathrm{H}_{2} \mathrm{O}_{2}$ treatment, the oxidative stress in Kunlun 14 was significantly lower than that in Ganpi6, further confirming that Kunlun 14 can better tolerate $\mathrm{Cd}$ stress. 


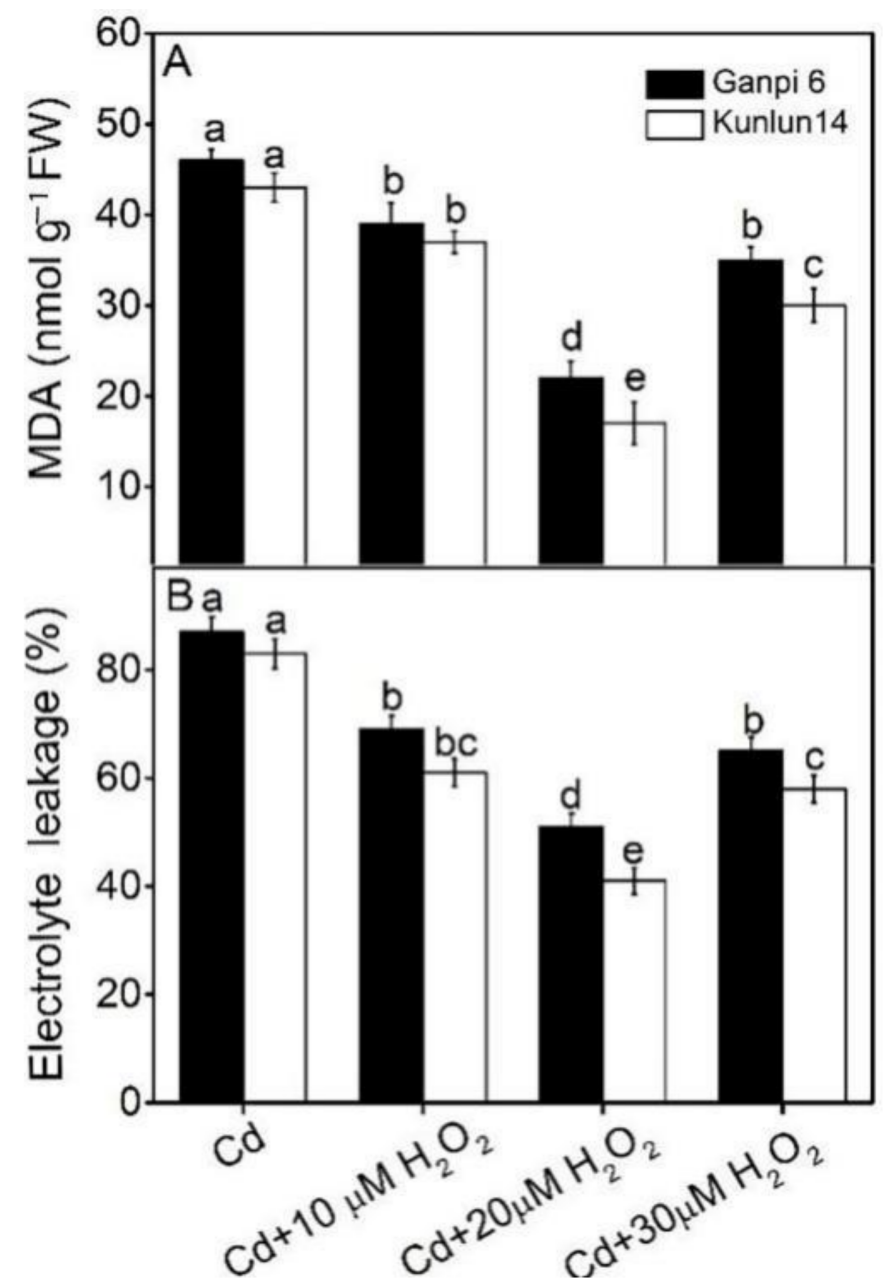

Figure 2. Effects of $\mathrm{H}_{2} \mathrm{O}_{2}$ on malondialdehyde content (MDA) (A) and electrolyte leakage (EL) (B) under Cd stress in Ganpi6 and Kunlun14 roots. Six-day-old seedlings were grown in 1/4-strengh Hoagland solution with $150 \mu \mathrm{M} \mathrm{Cd}$ and $10-30 \mu \mathrm{M} \mathrm{H}_{2} \mathrm{O}_{2}$ for $48 \mathrm{~h}(n=3)$. Different lower case letters represent significant difference at $p<0.05$.

\subsection{Exogenous $\mathrm{H}_{2} \mathrm{O}_{2}$ Enhances HvAOXs Expression in Ganpi6 and Kunlun14 Roots under Cd Stress}

Alternative pathway (AP) can be markedly induced when plants are exposed to various stresses [31]. Under stress conditions, $\mathrm{H}_{2} \mathrm{O}_{2}$ can significantly induce $A O X s$ expression and further promote AP capacity [32,33]. By far, HvAOXs had been cloned in our previous research [31]. The effect of $\mathrm{Cd}$ stress on $\mathrm{HvAOXs}$ expression was investigated. $\mathrm{HvAOXs}$ expression was up-regulated in Ganpi6 and Kunlun14 roots under Cd stress. In Ganpi6 and Kunlun14, the expression of $H v A O X 1 a, H v A O X 1 d 1$ and $H v A O X 1 d 2$ increased by $6.17 \times$ and $6.98 \times$, by $1.41 \times$ and $1.87 \times$, and by $86.04 \%$ and $105.13 \%$, respectively (Figure 3 ). Under $\mathrm{Cd}+\mathrm{SHAM}$ treatment, the expression level of HvAOXs was observably lowered. The effect of exogenous $\mathrm{H}_{2} \mathrm{O}_{2}$ on $\mathrm{HvAOXs}$ expression was further investigated. Under $\mathrm{Cd}+$ $\mathrm{H}_{2} \mathrm{O}_{2}$ treatment, the expression of $\mathrm{HvAOX} 1 \mathrm{a}$ was increased by $4.21 \times$ and $5.37 \times$ in Ganpi6 and Kunlun14 roots, respectively (Figure 3A), whereas HvAOX1d1 and HvAOX1d2 were just slightly induced (Figure 3B,C). When AP was inhibited by SHAM, the expression of $\mathrm{HvAOXs}$ was markedly reduced under $\mathrm{Cd}+\mathrm{H}_{2} \mathrm{O}_{2}+\mathrm{SHAM}$ treatment (Figure 3). These results suggested that AP might play a crucial role in $\mathrm{H}_{2} \mathrm{O}_{2}$-promoted $\mathrm{Cd}$ tolerance. 


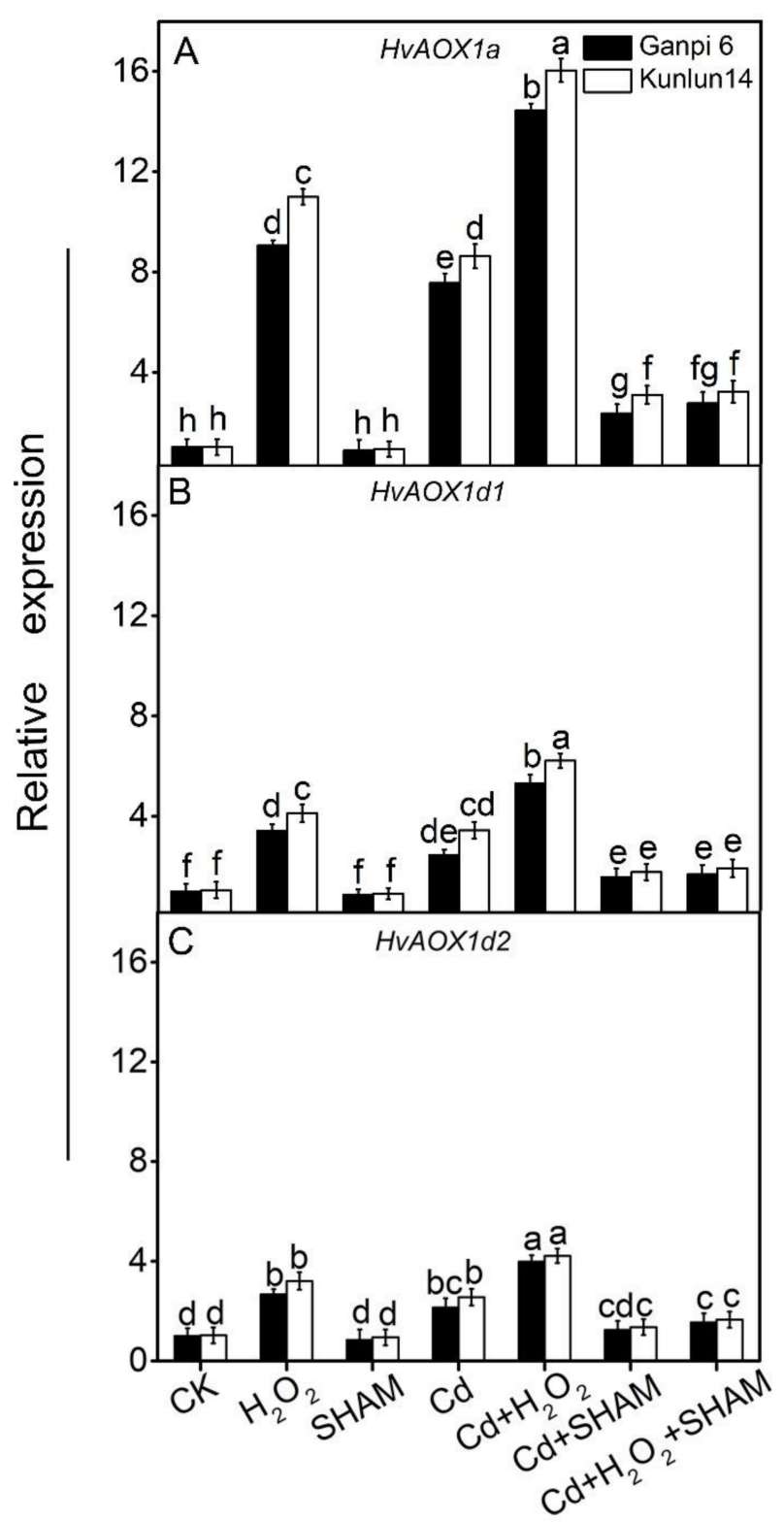

Figure 3. Effects of $\mathrm{H}_{2} \mathrm{O}_{2}$ on the expression of $\mathrm{HvAOXs}$ genes in Ganpi6 and Kunlun14 roots under $\mathrm{Cd}$ stress. (A) HvAOX1a; (B) HvAOX1d1; (C) HvAOX1d2. In this experiment, CK represented seedlings that grown normally without any treatment. $150 \mu \mathrm{M} \mathrm{Cd}, 20 \mu \mathrm{M} \mathrm{H}_{2} \mathrm{O}_{2}$, and $100 \mu \mathrm{M}$ salicylhydroxamic acid (SHAM) were used. HvACTIN was used as the reference gene $(n=3)$. Different lower case letters represent significant difference at $p<0.05$.

\subsection{Exogenous $\mathrm{H}_{2} \mathrm{O}_{2}$ Enhances AP Capacity $\left(V_{\text {alt }}\right)$ under $\mathrm{Cd}$ Stress}

To further explore the effect of exogenous $\mathrm{H}_{2} \mathrm{O}_{2}$ on respiration under $\mathrm{Cd}$ stress, changes in total respiration rate $\left(\mathrm{V}_{\mathrm{t}}\right)$, cytochrome pathway capacity $\left(\mathrm{V}_{\text {cyt }}\right)$ and $\mathrm{V}_{\text {alt }}$ were examined. As shown in Figure $4, \mathrm{~V}_{t}$ and $\mathrm{V}_{\text {alt }}$ were significantly increased under $\mathrm{H}_{2} \mathrm{O}_{2}$ treatment alone in Ganpi6 and Kunlun14 roots. Specifically, $\mathrm{V}_{\mathrm{t}}$ was increased by $2.88 \times$ and $3.02 \times$, and $V_{\text {alt }}$ was increased by $2.12 \times$ and $2.63 \times$ in Ganpi6 and Kunlun14, respectively. Under $\mathrm{Cd}$ treatment, $\mathrm{V}_{\mathrm{t}}, \mathrm{V}_{\text {alt }}$ and $\mathrm{V}_{\text {cyt }}$ were increased by $3.07 \times$ and $4.08 \times, 2.96 \times$ and $3.14 \times$, and $1.66 \times$ and $1.72 \times$ in Ganpi6 and Kunlun14 roots, respectively (Figure 4). Under $\mathrm{Cd}+\mathrm{H}_{2} \mathrm{O}_{2}$ treatment, $\mathrm{V}_{\text {alt }}$ was increased by $50.41 \%$ and $58.47 \%$ in Ganpi6 and Kunlun14 roots, respectively, compared with $\mathrm{Cd}$ treatment alone. In all these treatments, $\mathrm{V}_{\text {cyt }}$ had almost no changes. When AP was inhibited by SHAM under $\mathrm{Cd}$ stress, $\mathrm{V}_{\text {alt }}$ was decreased to the control level (Figure $4 \mathrm{~B}$ ). Under $\mathrm{Cd}+\mathrm{H}_{2} \mathrm{O}_{2}+$ SHAM treatment, $\mathrm{V}_{\mathrm{t}}$ was markedly 
reduced. These results indicated that $\mathrm{H}_{2} \mathrm{O}_{2}$-induced respiration is mainly achieved through enhancing $\mathrm{V}_{\text {alt }}$.

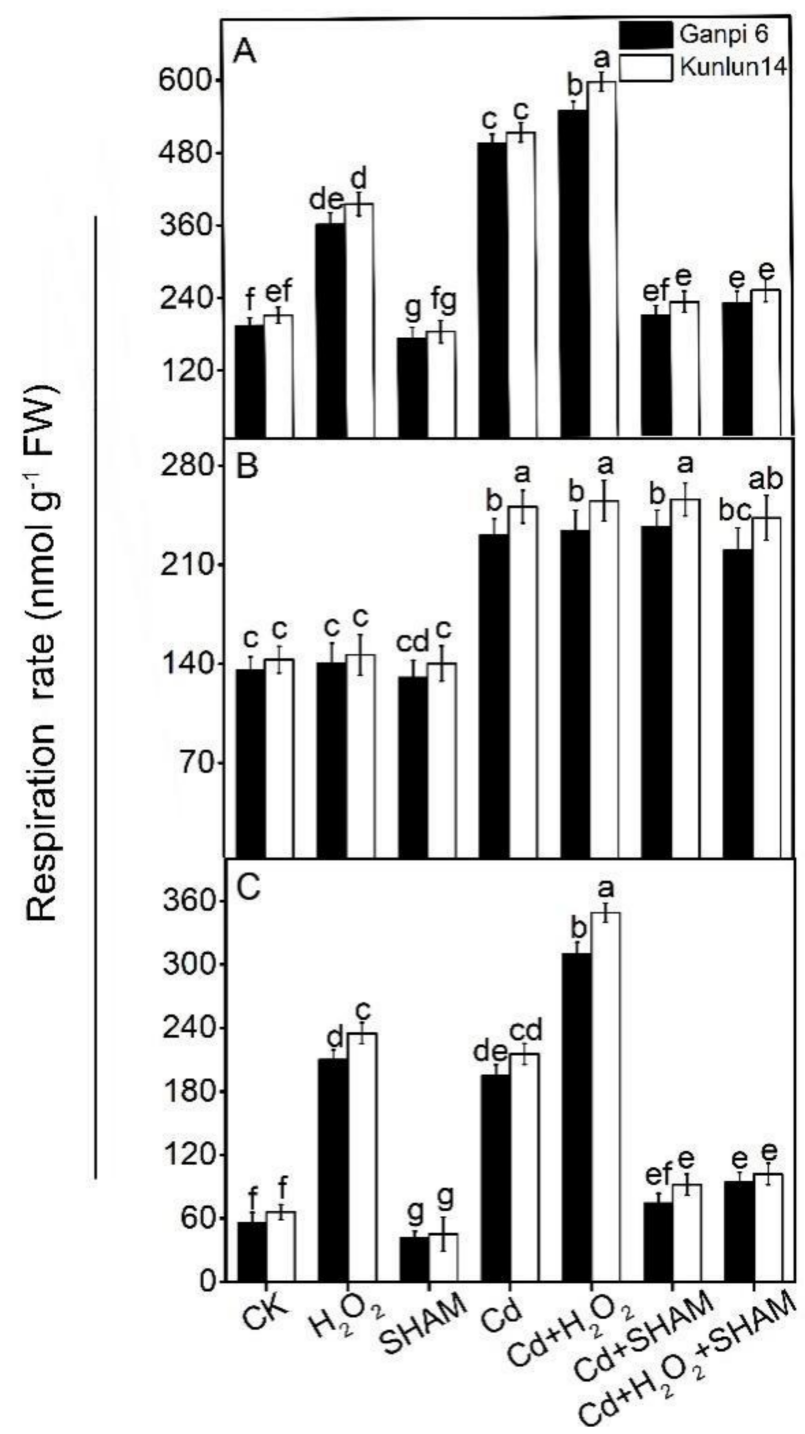

Figure 4. Effects of $\mathrm{H}_{2} \mathrm{O}_{2}$ and SHAM on respiration rates in Ganpi6 and Kunlun14 roots under $\mathrm{Cd}$ stress: (A) total respiration rate $\left(\mathrm{V}_{\mathrm{t}}\right)$; (B) cytochrome pathway capacity $\left(\mathrm{V}_{\text {cyt }}\right) ;(\mathbf{C})$ alternative pathway capacity $\left(\mathrm{V}_{\text {alt }}\right) .150 \mu \mathrm{M} \mathrm{Cd}, 20 \mu \mathrm{M} \mathrm{H}_{2} \mathrm{O}_{2}$, and $100 \mu \mathrm{M}$ SHAM were used $(n=3)$. Different lower case letters represent significant difference at $p<0.05$.

\subsection{Exogenous $\mathrm{H}_{2} \mathrm{O}_{2}$ Enhances AOX Protein Accumulation under Cd Stress}

To further analyze the effect of exogenous $\mathrm{H}_{2} \mathrm{O}_{2}$ on the alternative respiration under $\mathrm{Cd}$ stress, the AOX protein level was determined. Western blotting results showed that there was no significant difference in the AOX protein level between Ganpi6 and Kunlun14 under normal condition. Under the exogenous $\mathrm{H}_{2} \mathrm{O}_{2}$ treatment, the AOX protein level had no significant change in Ganpi6; but it was increased by $33.42 \%$ in Kunlun 14 compared with the control (Figure 5). The AOX protein content was significantly increased by $46.34 \%$ and $57.18 \%$ in Ganpi6 and Kunlun14 roots, respectively, under Cd stress. $\mathrm{H}_{2} \mathrm{O}_{2}$ treatment further enhanced the AOX protein level in both Ganpi6 and Kunlun14 under Cd stress, with the increase of $31.36 \%$ and $42.32 \%$, respectively, in comparison with the $\mathrm{Cd}$ stress alone. However, when AP was inhibited by SHAM under $\mathrm{Cd}+\mathrm{H}_{2} \mathrm{O}_{2}$ treatment, the AOX protein content was markedly reduced (Figure 5). These results indicated that $\mathrm{H}_{2} \mathrm{O}_{2}$ plays a regulatory role in the $\mathrm{Cd}$-induced $\mathrm{AOX}$ protein expression. 


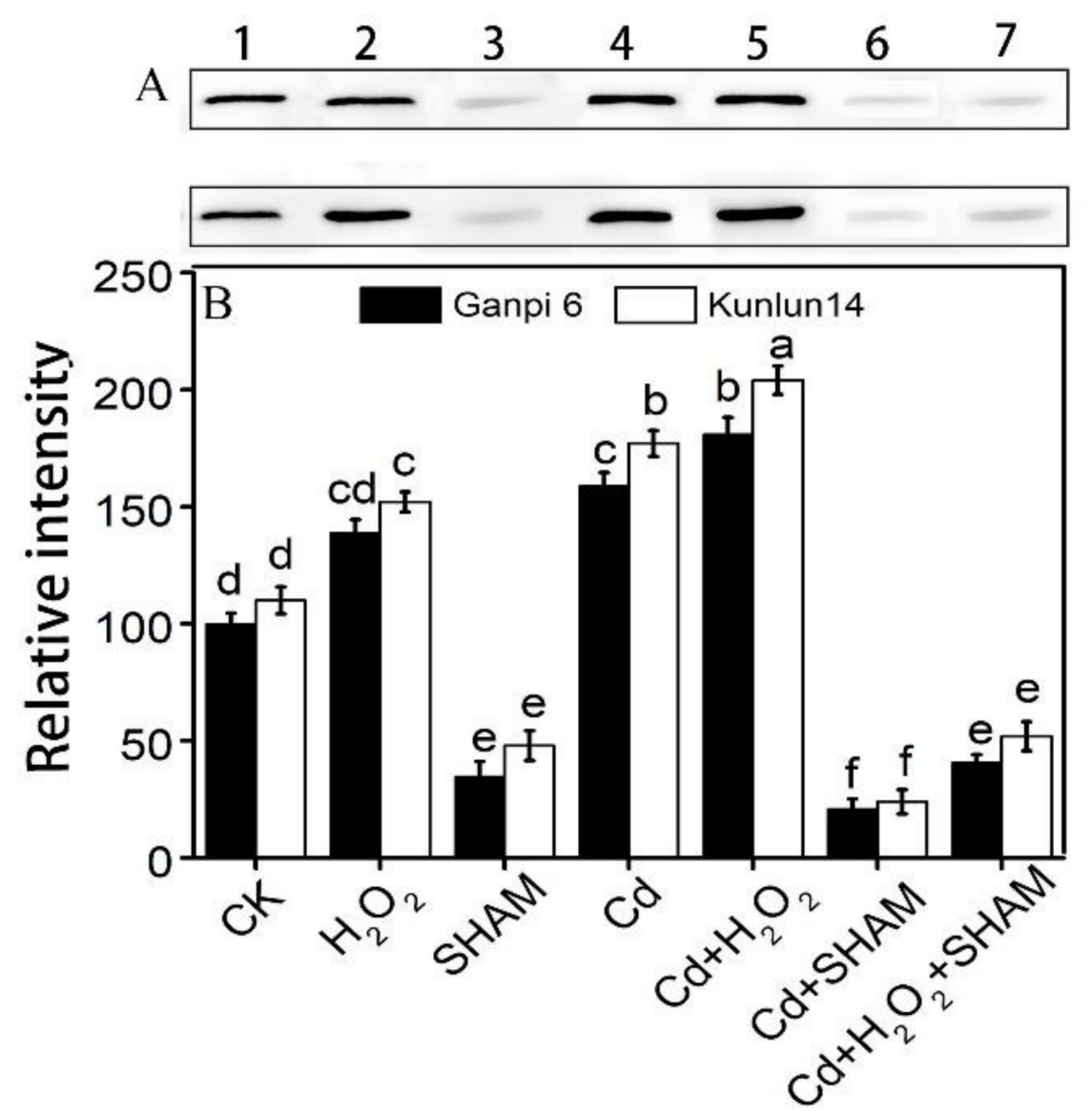

Figure 5. Effects of exogenous $\mathrm{H}_{2} \mathrm{O}_{2}$ on AOX protein level in Ganpi 6 and Kunlun 14 roots under Cd stress: (A) Western-blotting analysis of AOX protein; (B) quantification of AOX protein. In Figure 5, lane 1: CK; 2: $\mathrm{H}_{2} \mathrm{O}_{2}$; 3: SHAM; 4: $\mathrm{Cd}$; $5: \mathrm{Cd}+\mathrm{H}_{2} \mathrm{O}_{2}$; 6: $\mathrm{Cd}+\mathrm{SHAM}$; $: \mathrm{Cd}+\mathrm{H}_{2} \mathrm{O}_{2}+$ SHAM. AOX protein was quantified by using the ImageJ software $(n=3)$. Different lower case letters represent significant difference at $p<0.05$.

\subsection{AP Is Involved in the Regulation of $\mathrm{H}_{2} \mathrm{O}_{2}$ in Barley Tolerance to $\mathrm{Cd}$ Stress}

$\mathrm{AP}$ can improve plant tolerance to environmental stresses [31]. We further tested the relationship between MDA content or EL and AP upon Cd stress. Under Cd stress, in Ganpi6 and Kunlun14 roots, the MDA content was increased by $4.92 \times$ and $4.11 \times$, respectively, whereas EL level was increased by $2.74 \times$ and $2.13 \times$, respectively. $\mathrm{H}_{2} \mathrm{O}_{2}$ markedly relieved the Cd-induced oxidative stress. MDA content was decreased by $30.96 \%$ and $44.77 \%$ in Ganpi6 and Kunlun14, respectively, under $\mathrm{Cd}+\mathrm{H}_{2} \mathrm{O}_{2}$ treatment in comparison with Cd stress alone; whereas EL was decreased by $28.51 \%$ and $41.61 \%$, respectively (Figure 6). When AP was inhibited by SHAM under Cd stress, Cd-induced oxidative damage was intensified. The MDA content was increased by $35.96 \%$ and $39.65 \%$; and EL was increased by $28.51 \%$ and $31.54 \%$, respectively. Under $\mathrm{Cd}+\mathrm{H}_{2} \mathrm{O}_{2}+\mathrm{SHAM}$ treatment, in Ganpi6 and Kunlun14 roots, MDA content and EL were increased by $77.14 \%$ and $85.71 \%$, respectively, and by $60.27 \%$ and $65.11 \%$, respectively, in comparison with $\mathrm{Cd}+\mathrm{H}_{2} \mathrm{O}_{2}$ treatment (Figure 6). These results indicated that AP plays an important role in $\mathrm{H}_{2} \mathrm{O}_{2}$ alleviation of the $\mathrm{Cd}$-induced oxidative stress. 


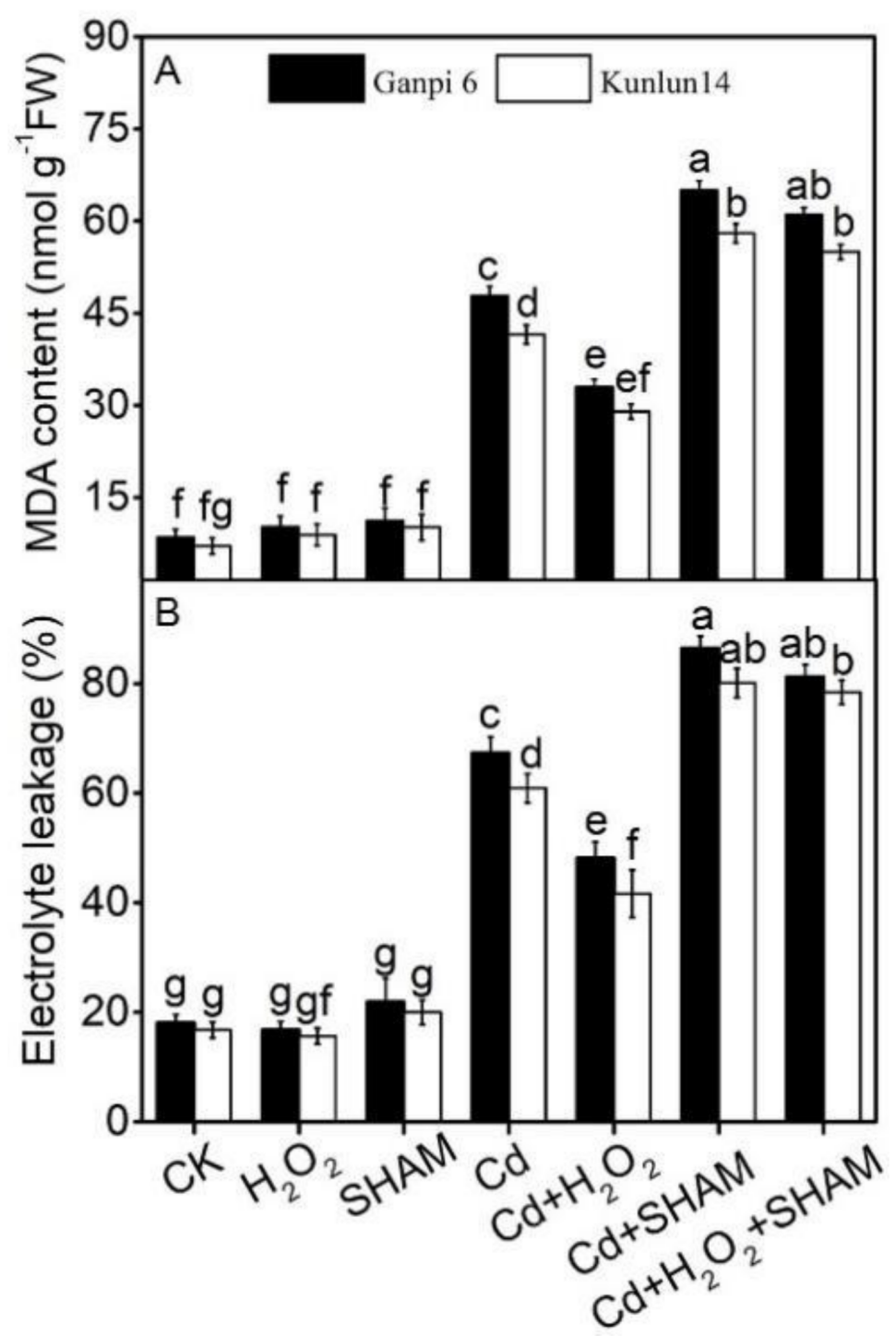

Figure 6. Effects of $\mathrm{H}_{2} \mathrm{O}_{2}$ and SHAM on MDA content (A) and electrolyte leakage (EL) (B) under Cd stress in Ganpi6 and Kunlun14 roots. Quantities of $150 \mu \mathrm{M} \mathrm{Cd}, 20 \mu \mathrm{M} \mathrm{H}_{2} \mathrm{O}_{2}$, and $100 \mu \mathrm{M} \mathrm{SHAM}$ were used $(n=3)$. Different lower case letters represent significant difference at $p<0.05$.

\subsection{Effects of $\mathrm{H}_{2} \mathrm{O}_{2}$ and SHAM on NADH/NAD ${ }^{+}$and $\mathrm{NADPH} / \mathrm{NADP} P^{+}$under $\mathrm{Cd}$ Stress}

Under stress conditions, AP inhibits the excessive ROS accumulation by consuming excessive reducing power in plants cells [33]. To further explore the effect of AP on the $\mathrm{H}_{2} \mathrm{O}_{2}$-improved $\mathrm{Cd}$ tolerance, NADH/NAD ${ }^{+}$and NADPH/NADP ${ }^{+}$ratios were examined. Under Cd stress, $\mathrm{NAD}^{+}$and $\mathrm{NADP}^{+}$contents were significantly decreased by $30.31 \%$ and $27.83 \%$ and by $29.14 \%$ and $27.77 \%$ in Ganpi 6 and Kunlun 14 roots, respectively. Comparatively, NADH and NADPH contents were increased by $57.61 \%$ and $37.62 \%$ and by $23.15 \%$ and $21.54 \%$ in Ganpi 6 and Kunlun 14 roots, respectively. Thus, the NADPH/NADP ${ }^{+}$ratio and $\mathrm{NADH} / \mathrm{NAD}^{+}$ratio were increased by $70.22 \%$ and $52.13 \%$ and by $127.05 \%$ and $69.34 \%$ in Ganpi 6 and Kunlun 14 roots, respectively (Figure 7). When AP was inhibited by SHAM under $\mathrm{Cd}$ stress, $\mathrm{NAD}^{+}$and $\mathrm{NADP}^{+}$contents were significantly decreased compared with $\mathrm{Cd}$ treatment alone; comparatively, NADH and NADPH contents were significantly increased (Figure 7). These results indicated that excessive reducing power was accumulated in barley roots under Cd stress; and AP can utilize the excessive reducing power. 


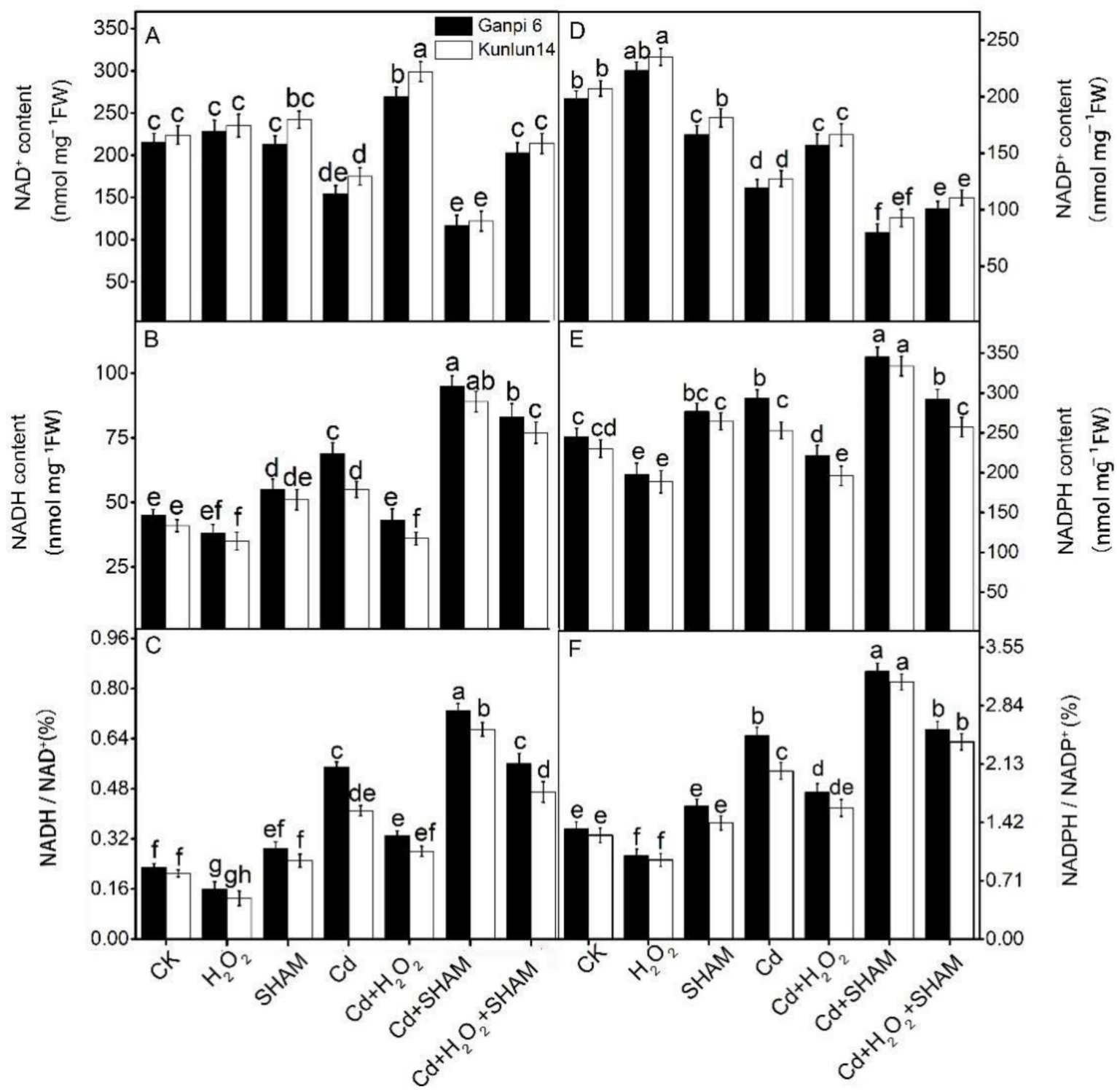

Figure 7. Effects of exogenous $\mathrm{H}_{2} \mathrm{O}_{2}$ and SHAM on $\mathrm{NAD}^{+}(\mathbf{A}) ; \mathrm{NADH}(\mathbf{B}) ; \mathrm{NADH} / \mathrm{NAD}^{+}(\mathbf{C}) ; \mathrm{NADP}^{+}$(D); NADPH (E); $\mathrm{NADPH}_{/ \mathrm{NADP}^{+}}(\mathbf{F})$ under Cd stress in Ganpi6 and Kunlun14 roots. $150 \mu \mathrm{M} \mathrm{Cd}, 20 \mu \mathrm{M} \mathrm{H}_{2} \mathrm{O}_{2}$, and $100 \mu \mathrm{M}$ SHAM were used $(n=3)$. Different lower case letters represent significant difference at $p<0.05$.

Under $\mathrm{Cd}$ stress, exogenous application of $\mathrm{H}_{2} \mathrm{O}_{2}$ resulted in the increase of NAD $\mathrm{NA}^{+}$ and $\mathrm{NADP}^{+}$contents and the decrease of NADH and NADPH contents (Figure 7). In comparison with $\mathrm{Cd}$ treatment alone, $\mathrm{NAD}^{+}$and $\mathrm{NADP}^{+}$contents were increased by $12.54 \%$ and $29.64 \%$ and by $26.13 \%$ and $33.34 \%$ in Ganpi 6 and Kunlun 14 roots, respectively, under $\mathrm{Cd}+\mathrm{H}_{2} \mathrm{O}_{2}$ treatment; while NADH and NADPH contents were decreased by $30.77 \%$ and $36.36 \%$ and by $18.18 \%$ and $24.43 \%$, respectively (Figure $7 \mathrm{~B}, \mathrm{E}$ ). Further results showed that the $\mathrm{NADPH} / \mathrm{NADP}^{+}$ratio and $\mathrm{NADH} / \mathrm{NAD}^{+}$ratio were significantly decreased under $\mathrm{Cd}+\mathrm{H}_{2} \mathrm{O}_{2}$ treatment (Figure $7 \mathrm{C}, \mathrm{F}$ ), which were reversed when AP was inhibited by SHAM. These results suggested that AP is involved in the $\mathrm{H}_{2} \mathrm{O}_{2}$-induced Cd tolerance in Ganpi 6 and Kunlun 14 roots, which was more obvious in Kunlun 14.

\subsection{Effects of Exogenous $\mathrm{H}_{2} \mathrm{O}_{2}$ and SHAM on the AsA-GSH Cycle under Cd Stress}

Under stress conditions, plants can remove excessive ROS by increasing antioxidant molecules (such as AsA and GSH) [32]. In order to investigate the effects of $\mathrm{H}_{2} \mathrm{O}_{2}$ and AP on antioxidant molecules under Cd stress, we checked the AsA and GSH contents. Under Cd stress, AsA and GSH contents were significantly increased by $1.14 \times$ and $1.59 \times$ 
and by $1.40 \times$ and $1.53 \times$ in Ganpi 6 and Kunlun 14 roots, respectively (Figure 8A,D). After adding exogenous $\mathrm{H}_{2} \mathrm{O}_{2}$ under Cd stress, AsA and GSH contents were further significantly increased by $38.03 \%$ and $48.27 \%$ and by $15.91 \%$ and $20.11 \%$ in Ganpi6 and Kunlun14 roots, respectively, compared to $\mathrm{Cd}$ treatment alone (Figure 8A,D). However, when AP was inhibited by SHAM under $\mathrm{Cd}$ or $\mathrm{Cd}+\mathrm{H}_{2} \mathrm{O}_{2}$ treatment, AsA and GSH contents had no significant changes (Figure 8). This suggested that $\mathrm{H}_{2} \mathrm{O}_{2}$ plays an essential role in regulating ASA and GAH levels under Cd stress. However, AP is not involved in this process.

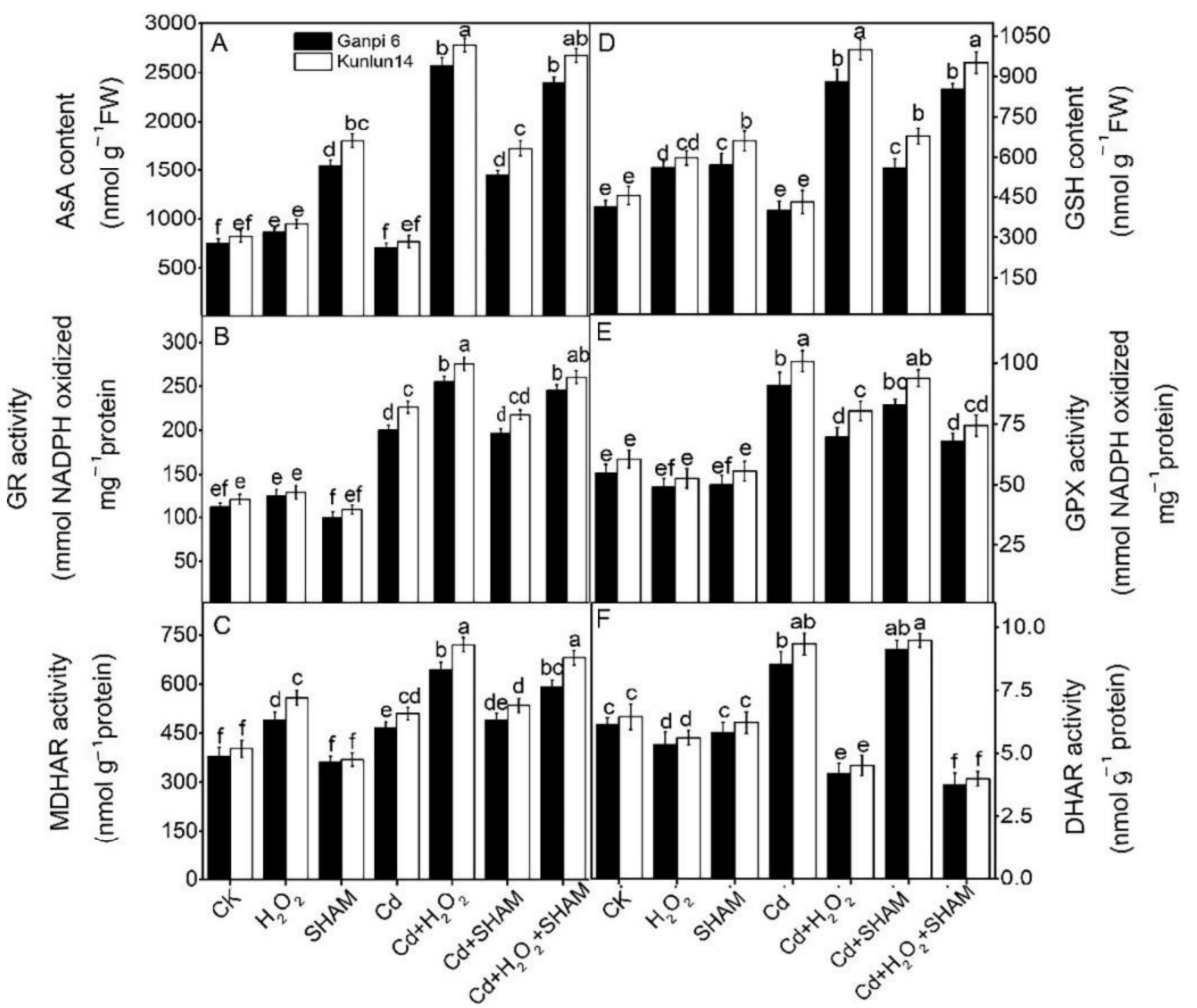

Figure 8. Effects of exogenous $\mathrm{H}_{2} \mathrm{O}_{2}$ and SHAM on AsA (A); GR (B); MDHAR (C); GSH (D); GPX (E); DHAR (F) under Cd stress in Ganpi6 and Kunlun14 roots. $150 \mu \mathrm{M} \mathrm{Cd}, 20 \mu \mathrm{M} \mathrm{H}_{2} \mathrm{O}_{2}$, and $100 \mu \mathrm{M}$ SHAM were used $(n=3)$. Different lower case letters represent significant difference at $p<0.05$.

GSH and AsA regeneration requires enzymes (GR, GPX, MDHAR and DHAR) in the AsA-GSH cycle. Thus, the activities of these enzymes were examined. The results showed that the enzyme activities were significantly increased under Cd stress in Ganpi6 and Kunlun14 roots. GR, MDHR, GPX and DHAR activities increased by $80.68 \%$ and $89.16 \%$, by $31.24 \%$ and $36.86 \%$, by $63.28 \%$ and $67.54 \%$, and by $40.33 \%$ and $44.11 \%$ in Ganpi6 and Kunlun14 roots, respectively. After adding exogenous $\mathrm{H}_{2} \mathrm{O}_{2}$ under $\mathrm{Cd}$ stress, the activities of GR and MDHAR were further significantly increased compared with $\mathrm{Cd}$ treatment alone, but the activities of GPX and DHAR were significantly decreased. When AP was inhibited under $\mathrm{Cd}+\mathrm{H}_{2} \mathrm{O}_{2}$ treatment, activities of these enzymes had no significant changes compared to $\mathrm{Cd}+\mathrm{H}_{2} \mathrm{O}_{2}$ treatment (Figure 8B,C,E,F). These results confirmed that AP is not involved in the $\mathrm{H}_{2} \mathrm{O}_{2}$-induced antioxidant enzyme activities in barley tolerance to Cd stress.

\subsection{Effects of Exogenous $\mathrm{H}_{2} \mathrm{O}_{2}$ and SHAM on Antioxidant Enzyme Activities under Cd Stress}

Under various environmental stresses, plants can eliminate excess ROS by stimulating antioxidant enzymes [31]. As shown in Figure 9, the activities of SOD, CAT, APX and POD were significantly increased under Cd stress. In Ganpi6 and Kunlun14 roots, SOD, CAT, APX and POD activities were increased by $28.61 \%$ and $35.84 \%$, by $50.41 \%$ and 
$56.72 \%$, by $16.32 \%$ and $22.81 \%$, and by $151.14 \%$ and $174.36 \%$, respectively. After adding the exogenous $\mathrm{H}_{2} \mathrm{O}_{2}$ under $\mathrm{Cd}$ stress, these antioxidant enzyme activities were further significantly increased compared with $\mathrm{Cd}$ treatment alone in Ganpi6 and Kunlun14 roots (Figure 9). When AP was inhibited by SHAM under $\mathrm{Cd}$ or $\mathrm{Cd}+\mathrm{H}_{2} \mathrm{O}_{2}$ treatment, there was no significant difference in the activities of the four enzymes compared with $\mathrm{Cd}$ treatment alone. It indicated that AP is not associated with antioxidant enzyme activities in the process of $\mathrm{H}_{2} \mathrm{O}_{2}$-improved the $\mathrm{Cd}$ tolerance.

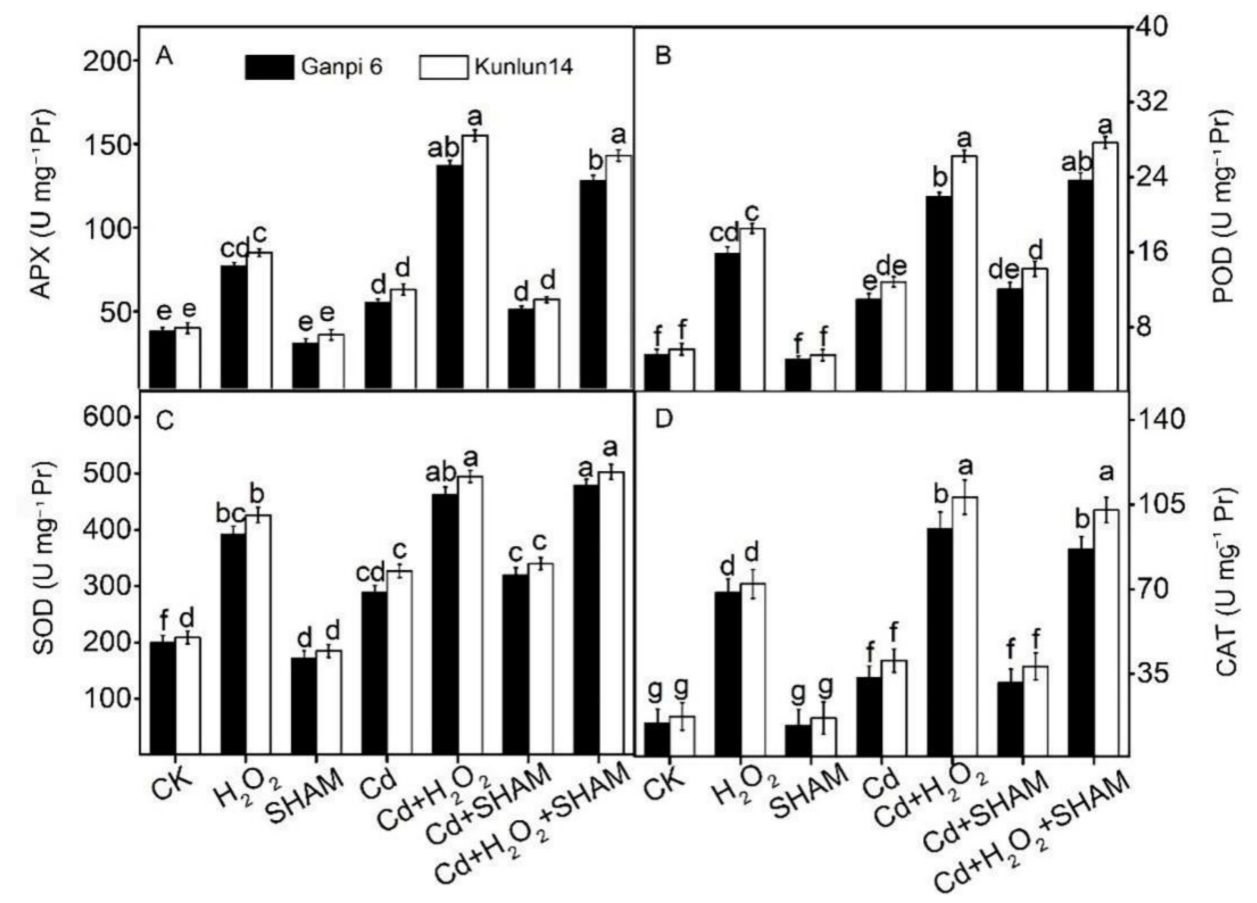

Figure 9. Effects of exogenous $\mathrm{H}_{2} \mathrm{O}_{2}$ and SHAM on APX (A); POD (B); SOD (C); CAT (D) under Cd stress in Ganpi6 and Kunlun14 roots. $150 \mu \mathrm{M} \mathrm{Cd}, 20 \mu \mathrm{M} \mathrm{H}_{2} \mathrm{O}_{2}$, and $100 \mu \mathrm{M}$ SHAM were used $(n=3)$. Different lower case letters represent significant difference at $p<0.05$.

\subsection{Effects of Exogenous $\mathrm{H}_{2} \mathrm{O}_{2}$ and SHAM on the Expression of Antioxidant Enzyme Genes under Cd Stress}

To further explore the mechanism of $\mathrm{H}_{2} \mathrm{O}_{2}$-induced enzyme activities, the expressions of antioxidant enzyme genes were analyzed under Cd stress. Cd stress significantly up-regulated the expression of HvMn-SOD, HvAPX, HvFe-SOD, HvCAT1, HvCAT2 and $H v P O D$, which were increased by $1.62 \times$ and $2.42 \times$, by $2.73 \times$ and $3.42 \times$, by $1.43 \times$ and $2.16 \times$, and by $3.98 \times$ and $4.69 \times$ in Ganpi6 and Kunlun14 roots, respectively. The expression of $\mathrm{Hv}-\mathrm{SOD}$ and $\mathrm{HvCAT2}$ had no difference compared with that in control. After adding exogenous $\mathrm{H}_{2} \mathrm{O}_{2}$ under $\mathrm{Cd}$ stress, the expression of $\mathrm{HvMn-SOD,HvAPX}$ and HvCAT1 was increased by $1.32 \times$ and $1.51 \times$, by $1.17 \times$ and $1.73 \times$, and by $2.32 \times, 2.98 \times$ in comparison with $\mathrm{Cd}$ treatment alone in Ganpi6 and Kunlun14 roots, respectively (Figure 10). However, the expression of other genes increased less than 1 time compared with Cd stress. When AP was inhibited under $\mathrm{Cd}$ or $\mathrm{Cd}+\mathrm{H}_{2} \mathrm{O}_{2}$ treatment, the expression of these antioxidant enzyme genes had no significant changes, further confirming that AP is not associated with the expression of antioxidant enzyme genes in the $\mathrm{H}_{2} \mathrm{O}_{2}$-improved Cd tolerance. 


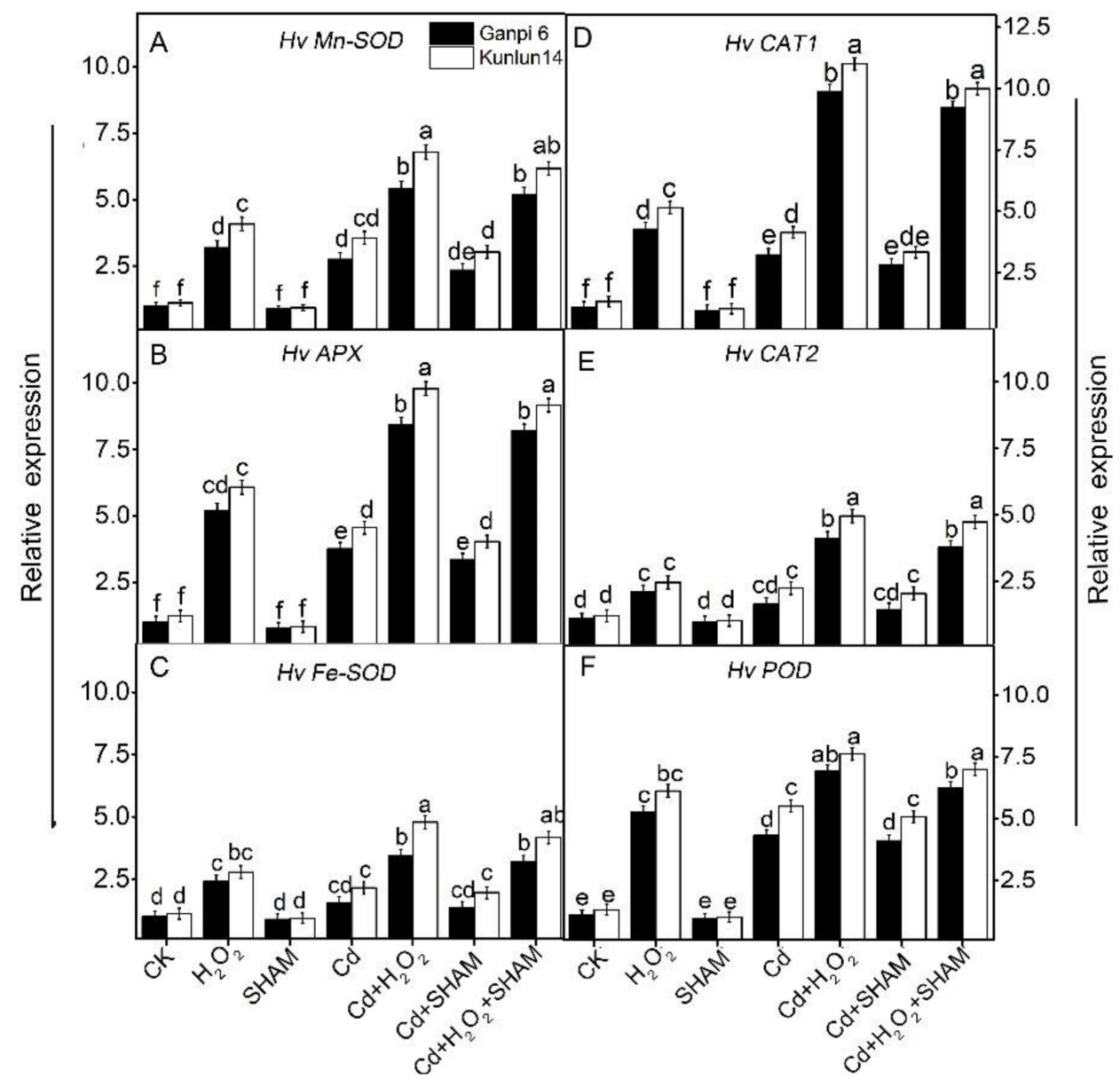

Figure 10. Effects of $\mathrm{H}_{2} \mathrm{O}_{2}$ on the expression of antioxidant enzyme genes in Ganpi6 and Kunlun14 roots under Cd stress. (A) HvMn-SOD; (B) HvAPX; (C) HvFe-SOD; (D) HvCAT1; (E) HvCAT2; (F) $\mathrm{HvPOD} .150 \mu \mathrm{M} \mathrm{Cd}, 20 \mu \mathrm{M} \mathrm{H}_{2} \mathrm{O}_{2}$, and $100 \mu \mathrm{M}$ SHAM were used $(n=3)$. HvACTIN was used as the reference gene. Different lower case letters represent significant difference at $p<0.05$.

\section{Discussion}

It has been reported that hulless barley showed the higher $\mathrm{Cd}$ tolerance than common barley [30]. This study aimed to explore the physiological role of $\mathrm{H}_{2} \mathrm{O}_{2}$ and alternative pathway (AP) in hulless barley response to Cd stress and the relationship between $\mathrm{H}_{2} \mathrm{O}_{2}$ and $\mathrm{AP}$ in this process.

$\mathrm{H}_{2} \mathrm{O}_{2}$, as a signal molecule, plays a central role in plant response to various stresses [10-12,26]. In this study, $20 \mu \mathrm{M} \mathrm{H}_{2} \mathrm{O}_{2}$ markedly counteracted the Cd-induced oxidative stress in barley (Figure 2), indicating that $\mathrm{H}_{2} \mathrm{O}_{2}$ can improve $\mathrm{Cd}$ tolerance in Kunlun14. Studies have indicated that AP can improve plant tolerance to heavy metal stresses by inhibiting the accumulation of ROS [23]. Our results showed that Kunlun14 maintains high $\mathrm{V}_{\text {alt }}$ under $\mathrm{Cd}$ stress (Figure 4C) and low oxidative damage (MDA content and EL; Figure 6) compared to Ganpi6. When AP was inhibited by SHAM, MDA content and EL were significantly increased in Kunlun14. This might be due to the dysfunction of AP causing over-reduction of the mitochondrial electron transport chain (mETC), and thus the excessive accumulation of ROS. Therefore, both $\mathrm{H}_{2} \mathrm{O}_{2}$ and AP are involved in $\mathrm{Cd}$ tolerance in hulless barley. What is their relationship in hulless barley response to $\mathrm{Cd}$ stress? Our results showed that after inhibiting AP under $\mathrm{Cd}$ stress, exogenous $\mathrm{H}_{2} \mathrm{O}_{2}$ cannot alleviate the Cd-induced oxidative stress, especially in Kunlun14 (Figure 6), indicating that the functional $\mathrm{AP}$ is required in the $\mathrm{H}_{2} \mathrm{O}_{2}$-induced Cd tolerance in Kunlun14.

Under stress conditions, AP consumes the excessive reducing power to prevent oxidative damage, thus enhances stress tolerance in plants [23]. An increased $V_{\text {alt }}$ was observed previously in high barley under low-nitrogen stress with decreased reducing 
power (NADH and NADPH) [20]. Similarly, $\mathrm{V}_{\text {alt }}$ was significantly higher in Kunlun14 than that in Ganpi6 (Figure 4C), while reducing power (NADH and NADPH) and oxidative damage indices (MDA and EL) were significantly lower in Kunlun14 (Figure 7A,D) under $\mathrm{Cd}$ stress. After applying $\mathrm{H}_{2} \mathrm{O}_{2}$ under $\mathrm{Cd}$ stress, $\mathrm{V}_{\text {alt }}$ was further significantly increased, however, NADH and NADPH contents were reduced (Figure 7A,D). When AP was inhibited by SHAM under $\mathrm{Cd}+\mathrm{H}_{2} \mathrm{O}_{2}$ treatment, NADH and NADPH contents were increased more in Kunlun14 than in $\mathrm{Cd}+\mathrm{H}_{2} \mathrm{O}_{2}$ treatment alone (Figure 7A,D), indicating that $\mathrm{H}_{2} \mathrm{O}_{2}$ can promote $\mathrm{AP}$ to remove more reducing power to alleviate the $\mathrm{Cd}$-induced oxidative damage.

Studies have shown that $\mathrm{H}_{2} \mathrm{O}_{2}$ can induce a significant increase of AP under environmental stresses [26]. It was reported that exogenous $\mathrm{H}_{2} \mathrm{O}_{2}$ induces the expression of AOX1 in Petunia hybrida under low temperature stress, and the AP capacity was also enhanced [34]. Application of exogenous $\mathrm{H}_{2} \mathrm{O}_{2}$ significantly increased the AP capacity and AOX protein content in petunia suspension cells [34]. Another study showed that application of exogenous $\mathrm{H}_{2} \mathrm{O}_{2}$ for 20 min under water stress, the AP capacity and the expression of $A O X 1$ family genes in wheat leaves were significantly increased [35]. Similar results were also observed in our observations. Exogenous $\mathrm{H}_{2} \mathrm{O}_{2}$ promoted more increase of $\mathrm{HvAOX1a}$ expression (Figure $3 \mathrm{~A}$ ), $\mathrm{V}_{\text {alt }}$ (Figure $4 \mathrm{C}$ ) and AOX protein (Figure 5) under $\mathrm{Cd}$ stress in Kunlun14 than in Ganpi6. Taken together, these results indicate that $\mathrm{H}_{2} \mathrm{O}_{2}$ can promote $\mathrm{AP}$ to remove more reducing power at $\mathrm{AOX}$ transcription, $\mathrm{AOX}$ protein, and $\mathrm{AP}$ capacity, thus enhancing the $\mathrm{Cd}$ tolerance in Kunlun14.

Antioxidant defense systems have been widely proven to be the core factor in plant defense against oxidative stresses [29-32]. Exogenous $\mathrm{H}_{2} \mathrm{O}_{2}$ significantly increased the AsA and GSH content in Kunlun14 and Ganpi6, which exhibited a similar pattern to a previous study in different species $[13,14,21]$. GR, GPX, MDHAR and DHAR are four key enzymes in the AsA-GSH cycle. GR catalyzes the reaction converting GSSG to GSH [27]. Both the GSH content and the GSH:GSSG ratio were all increased when GR was over-expressed in E. coli [36]. Application of exogenous $\mathrm{H}_{2} \mathrm{O}_{2}$ raised the GR activity, which resulted in increased GSH content in Cd-treated wheat seedlings [36]. As observed in our study, exogenous $\mathrm{H}_{2} \mathrm{O}_{2}$ also increased the GR activity, but decreased the GPX activity under $\mathrm{Cd}$ stress (Figure 8B,E). This might be the main reason for the high level of GSH content under $\mathrm{Cd}+\mathrm{H}_{2} \mathrm{O}_{2}$ treatment (Figure 8D). MDHAR and DHAR are two key enzymes in the AsA-GSH cycle, which maintain the homeostasis of AsA [28]. In wheat leaves, drought stress markedly increased the AsA content and the activities of MDHAR and DHHAR, which were further enhanced in the presence of $\mathrm{H}_{2} \mathrm{O}_{2}$ [36]. However, our observations showed that exogenous $\mathrm{H}_{2} \mathrm{O}_{2}$ increased the MDHAR activity, but decreased the DHAR activity (Figure $8 \mathrm{C}, \mathrm{F}$ ), which was inconsistent with previous study. This might be the main reason for the high AsA content under $\mathrm{Cd}+\mathrm{H}_{2} \mathrm{O}_{2}$ treatment.

Increasing findings have shown that the antioxidant enzyme activities are significantly increased under various stress conditions [30-33]. Similarly, in our results, these antioxidant enzyme activities were markedly elevated in Kunlun14 roots under Cd stress (Figure 9), and they were further enhanced in the presence of $\mathrm{H}_{2} \mathrm{O}_{2}$. It was consistent with the previous study in Petunia hybrida [34]. In addition, antioxidant enzyme genes (HvMnSOD, HvCAT1, $H v A P X)$ were significantly up-regulated (Figure 9), similar as observed in previous study in Medicago truncatula [29]. Furtherly, the Cd-induced oxidative stress was much relieved in Kunlun14 under $\mathrm{Cd}+\mathrm{H}_{2} \mathrm{O}_{2}$ treatment (Figure 6). This indicated that antioxidant defense systems play an important role in the $\mathrm{H}_{2} \mathrm{O}_{2}$-enhanced defense against oxidative stress in barley.

AP plays an important role in maintaining ROS homeostasis [32]. In addition, some studies have pointed out that AOX deficiency would lead to the increase of ROS-related scavenging enzyme activities [35]. Studies have shown that exogenous $\mathrm{H}_{2} \mathrm{O}_{2}$ can enhance the tolerance of mangrove to $\mathrm{Cd}$ stress by synergistic elimination of ROS through promoting $\mathrm{AP}$ and antioxidant enzyme activities [8]. The other report indicated that the exogenous $\mathrm{H}_{2} \mathrm{O}_{2}$ improved the tolerance of wheat to drought stress by jointly improving antioxidant 
enzymes and AP [33]. In this study, when AP was inhibited under $\mathrm{Cd}+\mathrm{H}_{2} \mathrm{O}_{2}$ treatment, antioxidant enzyme activities and antioxidant molecule contents had no significant changes, suggesting that AP is not involved in the $\mathrm{H}_{2} \mathrm{O}_{2}$-induced antioxidant defense system in highland barley tolerance to $\mathrm{Cd}$ stress. These results are not consistent with the previous studies [8,33], which might be ascribed to the differences in materials, stress conditions and treatment concentrations.

\section{Conclusions}

Above results clarified the physiological and molecular mechanisms of AP in $\mathrm{H}_{2} \mathrm{O}_{2}$ enhanced hulless barley $\mathrm{Cd}$ tolerance. Exogenous $\mathrm{H}_{2} \mathrm{O}_{2}$ promoted the expression of HvAOX1a (5.37×), HvAOX1d1 (1.87×), and HvAOX1d2 (1.06×), AOX proteins (42.32\%) and $\mathrm{V}_{\text {alt }}(58.47 \%)$ compared with $\mathrm{Cd}$ stress. $\mathrm{H}_{2} \mathrm{O}_{2}$ prevented the over-accumulation of ROS by enhancing AP to dissipating excess NADH/NAD ${ }^{+}(46.50 \%)$ and NADPH/NADP ${ }^{+}$ (40.21\%) ratios, ROS-related scavenging enzymes and antioxidant molecules. AP had no correlation with antioxidant defense system in $\mathrm{H}_{2} \mathrm{O}_{2}$-related hulless barley tolerance to $\mathrm{Cd}$ stress. In this study, we confirmed that AP plays a pivotal role in $\mathrm{H}_{2} \mathrm{O}_{2}$-elevated $\mathrm{Cd}$ tolerance in hulless barley.

Author Contributions: Y.B., L.Z., X.W. and X.N. designed the research; L.H., C.L., L.Y. and R.F. performed the experiments; L.H., Q.H. and S.W. analyzed the data; L.H., Y.B. and X.W. wrote the paper. All authors have read and agreed to the published version of the manuscript.

Funding: This research was funded by the Open Project Program of State Key Laboratory of Hulless Barley and Yak Germplasm Resources and Genetic Improvement (XZNKY-2021-C-014-K10); Youth Innovation Promotion Association of Chinese Academy of Sciences (Y201974); the National Natural Science Foundation of China [31972494]; Foundation of Science and Technology of Gansu Province (20JR5RA288).

Conflicts of Interest: Authors declares no conflict of interest.

\section{References}

1. Ismael, M.A.; Elyamine, A.M.; Moussa, M.G.; Cai, M.; Zhao, X.; Hu, C. Cadmium in plants: Uptake, toxicity, and its interactions with selenium fertilizerss. Metallomics 2019, 11, 255-277. [CrossRef] [PubMed]

2. Fasani, E.; Manara, A.; Martini, F.; Furini, A.; Dalcorso, G. The potential of genetic engineering of plants for the remediation of soils contaminated with heavy metals. Plant Cell Environ. 2018, 41, 1201-1232. [CrossRef] [PubMed]

3. Zheng, X.; Chen, L.; Li, X. Arabidopsis and rice showed a distinct pattern in ZIPs genes expression profile in response to Cd stress. Bot. Stud. 2018, 59, 22. [CrossRef]

4. Zhang, W.; Yun, L.; Zhao, Y.L.; Xu, Z.G.; Huang, H.M.; Zhou, J.K.; Yang, G.Y. Morphological and physiological changes of Broussonetia papyrifera seedlings in cadmium contaminated soil. Plants 2020, 9, 1698. [CrossRef] [PubMed]

5. Cui, W.N.; Wang, H.T.; Song, J.; Cao, X.; Rogers, H.J.; Francis, D.; Jia, C.Y.; Sun, L.Z.; Hou, M.F.; Tai, P.D.; et al. Cell cycle arrest mediated by Cd-induced DNA damage in Arabidopsis root tips. Ecotoxicol. Environ. Saf. 2017, 145, 569-574. [CrossRef]

6. Na, Q.C.; Lu, X.Y.; Guo, X.R.; Pan, Y.J.; Yu, B.F.; Tang, Z.H.; Guo, Q.X. Differential responses to Cd stress induced by exogenous application of $\mathrm{Cu}, \mathrm{Zn}$ or $\mathrm{Ca}$ in the medicinal plant Catharanthus roseus. Ecotoxicol. Environ. Saf. 2018, 157, $266-275$.

7. Sharma, S.S.; Dietz, K.J.; Mimura, T. Vacuolar compartmentalization as indispensable component of heavy metal detoxification in plants. Plant Cell Environ. 2016, 39, 1112-1126. [CrossRef]

8. Xie, X.; Weiss, D.J.; Weng, B.; Liu, J.; Lu, H.; Yan, C. The short-term effect of cadmium on low molecular weight organic acid and amino acid exudation from mangrove (Kandelia obovata (S., L.) Yong) roots. Environ. Sci. Pollut. Res. 2013, 20, 997-1008. [CrossRef]

9. Cuypers, A.; Smeets, K.; Ruytinx, J.; Opdenakker, K.; Keunen, E.; Remans, T.; Horemans, N.; Vanhoudt, N.; Van, S.S.; Van, B.F.; et al. The cellular redox state as a modulator in cadmium and copper responses in Arabidopsis thaliana seedlings. J. Plant Physiol. 2011, 168, 309-316. [CrossRef]

10. Huang, W.J.; Yang, X.D.; Yao, S.C.; Thet, L.; He, H.Y.; Wang, A.Q.; Li, C.Z.; He, L.F. Reactive oxygen species burst induced by aluminum stress triggers mitochondria-dependent programmed cell death in peanut root tip cells. Plant Physiol. Biochem. 2014, 82, 76-84. [CrossRef]

11. Malá, J.; Cvrčková, H.; Máchová, P.; Dostál, J.; Šíma, P. Heavy metal accumulation by willow clones in short-time hydroponics. J. For. Sci. 2010, 56, 28-34. [CrossRef]

12. Helmut, S. Hydrogen peroxide as a central redox signaling molecule in physiological oxidative stress: Oxidative eustress. Redox. Biol. 2017, 11, 613-619. 
13. Zhou, J.; Xia, X.J.; Zhou, Y.H.; Shi, K.; Chen, Z.; Yu, J.Q. OH1- dependent $\mathrm{H}_{2} \mathrm{O}_{2}$ production and subsequent activation of MPK1/2 play an important role in acclimation-induced cross-tolerance in tomato. J. Exp. Bot. 2014, 65, 595-607. [CrossRef] [PubMed]

14. Yildiz, M.; Terzi, H.; Bingül, N. Protective role of hydrogen peroxide pretreatmenton defense systems and BnMP1 gene expression in Cr (VI)- stressed canola seedlings. Ecotoxicology 2013, 22, 1303-1312. [CrossRef]

15. Pavel, V.; Fedurayev, K.S.; Mironov, D.A.; Gabrielyan, V.S.; Bedbenov, A.A.; Zorina, M.S.; Dmitry, A.L. Hydrogen peroxide participates in perception and transduction of cold stress signal in synechocystis. Plant Cell Physiol. 2018, 59, 1255-1264.

16. Helmut, S. Role of metabolic H2O2 generation: Redox signaling and oxidative stress. J. Biol. Chem. 2014, $289,8735-8741$.

17. Yang, C.Y. Hydrogen peroxide controls transcriptional responses of ERF73/HRE1 and ADH1 via modulation of ethylene signaling during hypoxic stress. Planta 2014, 39, 877-885. [CrossRef]

18. Vanlerberghe, G.C.; Day, D.A.; Wiskich, J.T.; Vanlerberghe, A.E.; McIntosh, L. AOX activity in tobacco leaf mitochondria: Dependence on tricarboxylic acid cycle-mediated redox regulation and pyruvate activation. Plant Physiol. 1995, 109, 353-361. [CrossRef] [PubMed]

19. Daurelio, L.D.; Checa, S.K.; Barrio, J.M.; Ottado, J.; Orellano, E.G. Characterization of Citrus sinensis type 1 mitochondrial alternative oxidase and expression analysis in biotic stress. Biosci. Rep. 2010, 30, 59-71. [CrossRef]

20. Wang, F.; Wang, X.M.; Zhao, C.Z.; Wang, J.F.; Li, P.; Dou, Y.Q.; Bi, Y.R. Alternative pathway is involved in the tolerance of highland barley to the low-nitrogen stress by maintaining the cellular redox homeostasis. Plant Cell Rep. 2016, 35, 317-328. [CrossRef]

21. Zhao, C.Z.; Wang, X.M.; Wu, K.; Li, P.; Chang, N.; Wang, J.F.; Wang, F.; Li, J.; Bi, Y.R. Glucose-6-phosphate dehydrogenase and alternative oxidase are involved in the cross tolerance of highland barley to salt stress and UV-B radiation. J. Plant Physiol. 2015, 181, 83-95. [CrossRef]

22. Castro-Guerrero, N.A.; Rodríguez-Zavala, J.S.; Marín-Hernández, A.; Rodríguez-Enríquez, S.; Moreno-Sánchez, R. Enhanced alternative oxidase and antioxidant enzymes under Cd2+ stress in Euglena. J. Bioenerg. Biomembr. 2008, 40, $227-235$. [CrossRef] [PubMed]

23. Jia, H.; Wang, X.; Dou, Y.; Liu, D.; Si, W.; Fang, H.; Zhao, C.; Chen, S.; Xi, J.; Li, J. Hydrogen sulfide-cysteine cycle system enhances cadmium tolerance through alleviating cadmium-induced oxidative stress and ion toxicity in Arabidopsis roots. Sci. Rep. 2016, 6, 39702. [CrossRef] [PubMed]

24. Yukioka, H.; Inagaki, S.; Tanaka, R.; Katoh, K.; Miki, N.; Mizutani, A.; Masuko, M. Transcriptional activation of the alternative oxidase gene of the fungus Magnaporthe grisea by a respiratory-inhibiting fungicide and hydrogen peroxide. Biochim. Biophys. Acta 1998, 1442, 161-169. [CrossRef]

25. Wang, H.H.; Huang, J.J.; Bi, Y.R. Induction of alternative respiratory pathway involves nitric oxide, hydrogen peroxide and ethylene under salt stress. Plant Signal. Behavior. 2010, 5, 1636-1637. [CrossRef] [PubMed]

26. Wang, H.H.; Huang, J.J.; Liang, X.L.; Bi, Y.R. Involvement of hydrogen peroxide, calcium, and ethylene in the induction of the alternative pathway in chilling-stressed Arabidopsis callus. Planta 2012, 235, 53-67. [CrossRef]

27. Paradiso, A.; Berardino, R.; Pinto, M.C.; Sanità, T.L.; Storelli, M.M.; Tommasi, F.; De, G.L. Increase in ascorbate-glutathione metabolism as local and precocious systemic responses induced by cadmium in durum wheat plants. Plant Cell Physiol. 2008, 49 , 362-374. [CrossRef] [PubMed]

28. Skórzyńska, P.E.; Dra, M.; Krupa, Z. The activity of the antioxidative system in cadmium-treated Arabidopsis thaliana. Biol. Plant. 2003, 47, 71-78. [CrossRef]

29. Jian, W.; Zhang, D.W.; Zhu, F.; Wang, S.X.; Pu, X.J.; Deng, X.G.; Luo, S.S.; Lin, H.H. Alternative oxidase pathway is involved in the exogenous SNP-elevated tolerance of Medicago truncatula to salt stress. J. Plant Physiol. 2016, 193, 79-87. [CrossRef]

30. He, L.; Wang, X.M.; Feng, R.J.; He, Q.; Wang, S.W.; Liang, C.F.; Yan, L.L.; Bi, Y.R. Alternative pathway is involved in nitric oxide enhanced tolerance to cadmium stress in barley roots. Plants 2019, 8, 557. [CrossRef] [PubMed]

31. Gandin, A.; Lapointe, L.; Dizengremel, P. The alternative respiratory pathway allows sink to cope with changes in carbon availability in the sink-limited plant Erythronium americanum. J. Exp. Bot. 2009, 60, 4235-4248. [CrossRef] [PubMed]

32. Ho, L.H.; Giraud, E.; Uggalla, V.; Lister, R.; Clifton, R.; Glen, A.; Thirkettle-Watts, D.; Van Aken, O.; Whelan, J. Identification of regulatory pathways controlling gene expression of stress-responsive mitochondrial proteins in Arabidopsis. Plant Physiol. 2008, 147, 1858-1873. [CrossRef] [PubMed]

33. Cvetkovska, M.; Vanlerberghe, G.C. Alternative oxidase impacts the plant response to biotic stress by influencing the mitochondrial generation of reactive oxygen species. Plant Cell Environ. 2013, 36, 721-732. [CrossRef]

34. Wagner, A.M. A role for active oxygen species as second messengers in the induction of alternative oxidase gene expression in Petunia hybrida cells. Febs Lett. 1995, 368, 339-342. [CrossRef]

35. Feng, H.; Duan, J.; Li, H.; Liang, H.; Li, X.; Han, N. Alternative respiratory pathway under drought is partially mediated by hydrogen peroxide and contributes to antioxidant protection in wheat leaves. Plant Prod. Sci. 2008, 11, 59-66. [CrossRef]

36. Sotirios, S.M.; Leondios, L.; George, P.; Evy, M.Z.; Georgios, A. Expression, purification, and physicochemical characterization of the N-terminal active site of human angiotensin-I converting enzyme. J. Pept. Sci. 2007, 13, 31-36. 